\title{
THE EFFECT OF COMMUNITY LANGUAGE LEARNING AND LEARNING INTEREST TOWARDS STUDENTS' SPEAKING ABILITY
}

\author{
Syahyuri \\ Program of English Education, Faculty of Language and Art, University of Indraprasta PGRI \\ Jalan Nangka No. 58C Tanjung Barat, Jagakarsa, Jakarta Selatan 12530 \\ yuri.syahyuri@gmail.com
}

\begin{abstract}
This research aims to get the empirical data and to find out the effect of Community Language Learning and learning interest towards students' speaking ability at a private college. The research is conducted at school of foreign languages Cipto Hadi Pranoto in Bekasi. The total sample of this research is 60 students. The data of teaching method and learning interest is collected by using questionnaires and the speaking ability is acquired from the test. The research instrument is tested by the validity and the reliability test. The data is analyzed by using two ways analysis of variance (ANOVA). The result of the research shows that the teaching method has significant effect to the students' speaking ability as the data shows that $\mathrm{F}_{0}$ is 936,941 and sig $0,000<0,05$. Learning interest has no significant effect to the students' speaking ability as the data shows that $F_{0}$ is 3, 603 sig 0,63>0,05. Teaching method and learning interest on speaking ability outcomes are not significant as the data shows that $\mathrm{F}_{0}$ is $3,603 \mathrm{sig} 0,63>0,05$. The results show that the null hypothesis $\left(\mathrm{H}_{0}\right)$ is accepted and the alternative hypothesis $\left(\mathrm{H}_{1}\right)$ is rejected.
\end{abstract}

Key words: community language learning, learning interest, speaking ability

\begin{abstract}
ABSTRAK
Penelitian ini bertujuan untuk memperoleh data empiris dan juga untuk mengetahui apakah ada pengaruh antara model pembelajaran Community Language Learning dan minat belajar terhadap kemampuan berbicara mahasiswa. Penelitian ini diadakan di sekolah tinggi bahasa asing Cipto Hadi Pranoto Bekasi. Jumlah sampel pada penelitian ini adalah 60 mahasiswa. Teknik pengumpulan data model pembelajaran dan minat belajar dilakukan dengan cara pemberian angket dan data kemampuan berbicara diperoleh melalui pemberian tes. Instrumen penelitian diuji dengan uji validitas dan reliabilitas. Data dianalisis dengan menggunakan analisis varians (ANOVA). Hasil penelitian menyimpulkan bahwa metode pengajaran berpengaruh signifikan terhadap kemampuan berbicara siswa, data menunjukkan bahwa $F_{0}$ adalah 936,941 dan sig 0,000 < 0,05. Minat belajar tidak berpengaruh signifikan terhadap kemampuan berbicara siswa, data menunjukkan bahwa FO adalah 3,603 sig 0,63>0,05. Metode pembelajaran dan minat belajar terhadap kemampuan berbicara tidak berpengaruh secara signifikan, data menunjukkan bahwa $\mathrm{FO}$ adalah 3,603 sig 0,63>0,05. Hasil penelitian menunjukkan bahwa hipotesis nol $\left(H_{0}\right)$ diterima dan hipotesis alternatif $\left(H_{l}\right)$ ditolak.
\end{abstract}

Kata kunci: community language learning, minat belajar, kemampuan berbicara. 


\section{INTRODUCTION}

The four language skills namely listening, speaking, reading, and writing are the basic subjects taught in English department at a college. Speaking is the most vital one. It is about to carry out conversation in a language. Speaking is an interactive process of constructing meaning that involves producing and receiving and processing information. It is often spontaneous, open-ended, and evolving (Bailey, 2005).

Speaking is, moreover, one of our most complex cognitive, linguistics and motor skills. It is usually followed by gesture or body movement. It requires extensive interaction between a person with lecturers, parents, peers, and other member of language community which is unique to our species that requires the feeling.

Many students prefer to keep quiet in the class, they might commit errors in grammar or pronunciation, and their classmates might laugh at them. This is alarming most especially when a student is in speaking subject and the whole semester only has a little bit progress for some shy students, otherwise, speaking subject at the college aims at making the students gain confidence in oral communication through practice.

In order to make the students speak fluently, the lecturers should always give them chances to involve in the teaching and learning process. Fluency in speaking English is one of the main objectives in learning English, because by being active in speaking they can be easier in communicating the idea, thinking, and feeling in any situation.

The factor that improves the students' success in learning English especially speaking is the students' interest. Learning interest is a kind of positive attitudes towards English learning as a foreign language.

Student's interest is naturally related to the students' desire to participate in the learning process. But it also concerns to the reasons or goals that underlie their involvement or noninvolvement in the academic activities. Although students equally have interest in learning, the source of their interest may differ one from another.

Learning interest is a kind of positive attitude towards the learning of English as a foreign language. Through becoming good learners and learning how to learn, the students are expected to be as skillful learners while continuing to have interest, motivation, and fun with the learning experiences.

According to Marimba (1999:79), "Interest is the tendency of soul towards something consisting of interest in it, which is generally containing with pleasure feeling towards something". Interest will appear if every individual is interested in something which he/she thinks that it is very important for him/her and can fulfill the basic needs.

Moreover, Syah (1995:136) stated that "Interest is the high soul tendency or high desire to something". In addition, according to Sudirman (2004:76) "Interest is a condition happening if someone looks the characteristic of a condition related to the desire or needs". So it could be concluded that interest is the permanent tendency to pay attention and remember some activities continuously and happily without someone's instruction.

The students' interest to learn English is also affected by the method provided by lecturers. There are many teaching methods developed by many experts. One of the methods that have been well known and used internationally is Community Language Learning. It is a method made by Charles A Curran. Charles is a specialist and professor on counseling and psychology. It means that this method is inspired by 
Counseling-Learning.

Counseling is a person who gives advice, assistance, and support to one who has problem or is in some way need. Community language learning draws on the counseling metaphor to redefine the roles of the teacher (the counselor) and learners (the clients) in the language classroom. The basic procedures of community language learning can thus be seen as derived from the counselorclient relationship, as stated by Richards and Rogers (2001) that if the concept of counseling and its application in community language learning are compared, the language teaching tradition of CLL represents the underlying concepts of the clientcounselor relationship in psychological counseling.

The counselor advises and supports the clients who have problems. This kind of relationship is considered basic to learning a foreign language. CLL sees a language learner as the whole person, including psychological aspects such as emotions and feeling. CLL methods are also described as humanistic methods.

CLL represents an attempt to put insights from psychology to work in the teaching and learning of foreign languages. The method emphasizes on community learning as opposed to individual learning as some other traditional teaching do. The concept of community has been used in this language learning method when the relationship between teacher and students build an intense atmosphere of warmth, and it is really relevant with the statement from Curran as quoted by setiyadi (2006), that language learners never feel isolated and alone because everybody belongs to the group and everybody sits in a community and senses positive regard to everyone else.

Below is the chart showing the close relationship between psychological counseling and community language learning:

\begin{tabular}{c|l}
\hline & Psychological Counseling \\
\hline 1 & $\begin{array}{l}\text { Client and counselor agree to } \\
\text { counseling }\end{array}$ \\
\hline 2 & $\begin{array}{l}\text { Client articulates his/her } \\
\text { problems in language of effect }\end{array}$ \\
\hline 3 & Counselor listens carefully \\
\hline 4 & $\begin{array}{l}\text { Counselor restates client } \\
\text { message in language of } \\
\text { cognition }\end{array}$ \\
\hline 5 & $\begin{array}{l}\text { Client evaluates the accuracy of } \\
\text { counselor's message restatement }\end{array}$ \\
\hline 6 & $\begin{array}{l}\text { Client reflects on the interaction } \\
\text { of counseling session }\end{array}$ \\
\hline
\end{tabular}

\begin{tabular}{c|l}
\hline & $\begin{array}{l}\text { Community Language } \\
\text { Learning }\end{array}$ \\
\hline 1 & $\begin{array}{l}\text { Learner and knower (teacher) } \\
\text { agree to language learning }\end{array}$ \\
\hline 2 & $\begin{array}{l}\text { Learner presents to the knower } \\
\text { (in L1) a message he/she wishes } \\
\text { to deliver to another }\end{array}$ \\
\hline 3 & $\begin{array}{l}\text { Knower listens and other } \\
\text { learners overhear }\end{array}$ \\
\hline 4 & $\begin{array}{l}\text { Knower restates learner's } \\
\text { message in L2 }\end{array}$ \\
\hline 5 & $\begin{array}{l}\text { Learner repeats the L2 message } \\
\text { form to its addressee }\end{array}$ \\
\hline 6 & $\begin{array}{l}\text { Learner replays (from tape or } \\
\text { memory) and reflects upon the } \\
\text { message exchanged during the } \\
\text { language class. }\end{array}$ \\
\hline
\end{tabular}

Community language learning is an approach in which students work together to develop what aspects of a language they would like to learn. The teacher acts as a counselor and a paraphraser, while the learner acts as a collaborator, although sometimes this role can be changed.

There are five important principles in Community Language Learning 
according to Stevick as quoted by Pateda (1991), who state those principles as the followings:

1. Language is a behavior of a learner that is directed towards others. The learner can talk about things that make him interested and things that he has been experienced before.

2. A learner can learn a new behavior fast if he is not interrupted. Therefore a leaner as the client must have as many opportunities as possible to practice his language knowledge without much interference from the teacher as the counselor.

3. The counselor should give assistance the clients in using their language all the time.

4. The counselor should give assistance in maintaining useful behavior by using three suggested techniques, they are (a) give the chance to clients to talk much, (b) develop the language productivity of the clients and (c) give the counseling and then make some evaluations.

5. In preparing the materials, the counselor should choose the easy ones for both the clients and counselor which are suitable for the level and goal to be accomplished.

The principles of Community Language Learning above is summarized in a simple procedure as presented in a first day of CLL class by Storing in Stevick as quoted by Setiyadi (2006) as below:

1. The class begins with an informal meeting and everyone introduce himself or herself.

2. The knower makes a statement of the goal and guidelines for the course.
3. They form a circle so that everyone has visual contact with one another and everyone is within easy to conversation.

4. A volunteer student initiates conversation with other students by giving a message in their mother tongue.

5. The knower goes and stands behind the student, whispers an equivalent translation of the message in the target language.

6. The student repeats the message that has been translated into the target language.

7. Each student in the group has a chance to express his massage what their gets from the leader.

8. The knower always stands behind the students who are saying their statements and translate their message in the target language.

9. Each student repeats his message in the target language.

10. The knower chooses sentences to write on the blackboard that highlight some elements of language, such as grammar, vocabulary (translation) or pronunciation.

11. The students may ask questions about any of the elements discuss.

12. The knower encourages the students to copy sentences from the blackboard including the translation in their mother tongue. The copy becomes their textbook for home study.

Community language learning is an interesting method to discuss. Therefore, the researcher is interested to conduct the research about The Effects of Community Language Learning and Learning Interest towards Student's Speaking Ability. 


\section{METHOD}

The population of the research was drawn on the second semester STBA CHP Bekasi. The college was chosen as the location of the population because the college is located in the territory of Bekasi where the writer lives and the writer is the speaking and conversation lecturer at this college as well.

This study applied experimental design by using non-randomized or nonequivalent control group pre-test and post-test since the goal of the study was to investigate the effectiveness of certain method. The design is used because of the limitation of time and college regulation. Besides, it is also due to impracticable random assignment of school and classroom.

\section{RESULTS AND DISCUSSION Data Description}

The data description in this

Table 1

The Description of Statistics based on the Design of Research on Output Format of SPSS.

\section{Descriptive Statistics}

Dependent Variable: $Y$

\begin{tabular}{|ll|c|r|r|}
\hline A & B & Mean & Std. Deviation & \multicolumn{1}{c|}{ N } \\
\hline A1 & Bi & 79,8803 & 3,33106 & 15 \\
& B2 & 78,1720 & 2,61808 & 15 \\
& Total & 79,0261 & 3,06926 & 30 \\
\hline A2 & Bi & 44,7000 & 5,74705 & 15 \\
& B2 & 47,1000 & 4,39236 & 15 \\
& Total & 45,9000 & 5,17187 & 30 \\
\hline Total & Bi & 62,2901 & 18,47657 & 30 \\
& B2 & 62,6360 & 16,19608 & 30 \\
& Total & 62,4631 & 17,22680 & 60 \\
\hline
\end{tabular}

\section{The Hypothesis Test}

After the test of normality and homogeneity are done, the result show that the samples are from normal distribution population and variant sample are homogenous, then finally the research is intended to present the data found in the research on "the effect of Community Language Learning and Learning Interest towards students' speaking ability."

This research is about experimental research using two analysis vectors, those are analysis vector on learning method (A) and analysis vector on learning interest (B), each vector consists of two sub vectors, they are called Levels. There are two levels for vector of learning method, first is level of experiment by certain method (A1) and second is level of conventional method (A2). Another analysis vector is learning interest with two levels, first, high motivated students (B1), and second low motivated students (B2). The summary of the result of the calculation is shown in the table 4.1 as follows: 
by $\boldsymbol{t}$-test to determine the differences between each group significantly (simple effect). In other words, the t-test is used in order to see which sample group has higher speaking result based on the learning interest level. The summary of the data analysis using ANOVA can be seen in the following table.

Table 2

The Statistic of Hypotheses Test Using Two-Way ANOVA

Tests of Between-Subjects Effects

Dependent Variable: $Y$
\begin{tabular}{|l|r|r|r|r|r|} 
Source & $\begin{array}{c}\text { Type III Sum } \\
\text { of Squares }\end{array}$ & df & Mean Square & \multicolumn{1}{c|}{ F } & \multicolumn{1}{c|}{ Sig. } \\
\hline Corrected Model & $16525,197^{\text {a }}$ & 3 & 5508,399 & 313,549 &, 000 \\
Intercept & 234098,082 & 1 & 234098,082 & 13325,312 &, 000 \\
A & 16460,111 & 1 & 16460,111 & 936,941 &, 000 \\
B & 1,794 & 1 & 1,794 &, 102 &, 750 \\
A*B & 63,292 & 1 & 63,292 & 3,603 &, 063 \\
Error & 983,804 & 56 & 17,568 & & \\
Total & 251607,083 & 60 & & & \\
Corrected Total & 17509,001 & 59 & & & \\
\hline
\end{tabular}

a. R Squared = ,944 (Adjusted R Squared $=, 941)$

Based on the data above, the hypothesis that is proposed can be answered. The description of the discussion is as follows:

\section{The Effect of Learning Method (CLL) towards Students' Speaking Ability.}

Based on the result of the summary table of the ANOVA (SPSS output) shows that the score of $F_{0}$ is 936,941 and sig $0,000<0,05$, so the null hypotheses $\left(\mathrm{H}_{0}\right)$ is rejected and alternative hypotheses $\left(\mathrm{H}_{1}\right)$ is accepted. It proves that the difference in the average (mean) of student learning outcomes on speaking that is taught by using experimental method with students taught by conventional method is different significantly. Students who are taught by using experimental method (X $\mathrm{A} 1=79,02$ ) have higher speaking score than those who are taught by conventional method (X A2 $=45,90$ ). Based on these data, it can be concluded that there is a significant effect of learning methods towards students' speaking ability. On other words, there is a difference in speaking outcomes of students who are taught by using experimental method with students taught by conventional method.

\section{The Effect of Student's Learning Interest towards Students' Speaking Ability.}

Based on the result of the summary table of the ANOVA (SPSS output) shows that $F_{0}$ is 0,102 and sig $0,750>$ 0 , 05, the null hypothesis (Ho) is accepted and the alternative hypothesis $\left(\mathrm{H}_{1}\right)$ is rejected. It proves that the difference in the average (mean) of learning speaking outcomes of students who have high learning interest with students who have low learning interest on the speaking subject is no significant difference in which students who have high learning interest $(\mathrm{X} \mathrm{B1}=62,29)$ and $(\mathrm{X} \mathrm{B} 2=62,63)$ do not differ significantly. Based on these data we can 
conclude that there is no effect on students' learning interest towards students' speaking ability. In other words, there is no difference between high interest students and low interest students.

\section{The Effect of Learning Method} (CLL) and Learning Interest towards Students' Speaking Ability.

Based on the result of the summary table of the ANOVA (SPSS output) shows that $F_{0}$ is 3, 603 sig $0,63>0,05$, the null hypothesis $\left(\mathrm{H}_{0}\right)$ is accepted and the alternative hypothesis $\left(\mathrm{H}_{1}\right)$ is rejected. It proves that learning method (CLL) and learning interest on speaking ability outcomes is not significant. Adjusted R. Squared is 0, 941, meaning that the variability of learning speaking outcomes that can be explained by the variable of learning method (CLL), learning interest, and the interaction of both on the subject of speaking is 94 , $1 \%$.

Based ANOVA results, it appears that the interaction between teaching methods and students' learning interest are not significant interaction. Since there is no interaction.

\section{CONCLUSION}

Based on the data obtained, the result of hypothesis testing and the discussion of the result of the research, it can be concluded that:

1. There is a significant effect of learning method towards students' speaking ability.

2. There is no effect of learning interest towards students' speaking ability.

3. There is no significant effect of the interaction between the granting of teaching method and learning interest towards students' speaking ability.

The research findings that have been discussed can be used as the consideration for the lecturer to choose an appropriate teaching method to be applied in a certain class. Lecturers should realize that every class has different condition. The lecturer should be able to choose a certain method that can encourage students to get actively involved in the language learning and teaching process.

There are various kinds of teaching methods. CLL has its own strength and weaknesses. Some students get more benefit of using a certain teaching method while some others do not. This is due to the fact that the students have different preferences towards a certain teaching method. If the teaching method matches the students' preference, they will learn better and more quickly.

\section{REFERENCES}

Bailey, K. M., \& Nunan, D. (2005). Practical English Language Teaching Speaking. New York: McGraw-Hill.

Marimba, A. D. (1999). Islam Education Philosophy Acknowledgment. Bandung: PT Al-Ma'arif.

Pateda, M. (1991). Linguistik Terapan. Flores: Nusa Indah.

Richards, J. C., \& Rodgers, T. S. (2001). Approaches and Methods in Language Teaching. Cambridge: Cambridge University Press.

Setiyadi, B. (2006). Teaching English as Foreign Language. Yogyakarta: Graha Ilmu.

Sudirman, A. M. (2004). Studying and Learning Motivation. Jakarta: PT. Raja Grafindo Persada.

Syah, M. (1995). Education Psychology. Bandung: Remaja Rosda Karya 